Disponível em

http://www.anpad.org.br/rac

RAC, Rio de Janeiro, v. 17, n. 3, art. 3,

pp. 304-324, Maio/Jun. 2013

(oc) EY-No

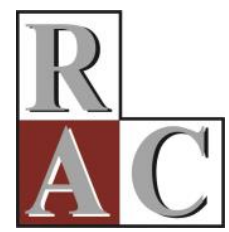

\title{
Ownership Concentration, Top Management and Board Compensation
}

Marcos Barbosa Pinto

E-mail: mpinto@gaveainvesst.com.br

Gávea Investimentos Av. Ataulfo de Paiva, 1100, $7^{\circ}$ andar, Rio de Janeiro, RJ, 22440-035, Brasil.

Ricardo Pereira Câmara Leal

E-mail: ricardoleal@coppead.ufrj.br

Universidade Federal do Rio de Janeiro - COPPEAD/UFRJ Caixa Postal 68514, Rio de Janeiro, RJ, 21941-972, Brasil. 


\title{
Resumo
}

O grau de concentração acionária pode influenciar a remuneração dos administradores (Bebchuk \& Fried, 2003). Este artigo analisa esta relação. Informações detalhadas sobre a remuneração da diretoria e do conselho de administração passaram a estar disponíveis a partir de 2010 por meio do Formulário de Referência da Comissão de Valores Mobiliários. Os modelos de regressão linear estimados com base em uma amostra de 315 companhias brasileiras com ações negociadas em bolsa de valores indicam uma correlação negativa econômica e estatisticamente significativa entre a remuneração dos administradores e o grau de concentração acionária. Ceteris paribus, companhias com menor grau de concentração acionária pagam remuneração maior a seus administradores. Empresas com controle familiar pagam mais a seu executivo principal, mas não à diretoria como um todo, e a remuneração dos conselheiros é maior com a proporção de membros do grupo de controle ou seus familiares no conselho de administração. Houve sustentação para a Hipótese do Poder dos Gestores nas companhias com menor grau de concentração acionária e para a extração de benefícios privados nas companhias onde ele é maior.

Palavras-chave: remuneração de administradores; grau de concentração acionária; governança corporativa; custos de agência; hipótese do poder dos gestores.

\begin{abstract}
The degree of ownership concentration may influence executive and board compensation (Bebchuk \& Fried, 2003). This article analyzes this relationship. Detailed information about top management and board compensation became available starting in 2010 through new Securities Commission filings. Linear regression models applied to a sample of 315 Brazilian companies traded on the national exchange indicate a negative and statistically significant economic correlation between executive compensation and the degree of ownership concentration. Ceteris paribus, companies with a lower degree of ownership concentration pay higher compensation to top executives. Family controlled companies pay more to their chief executive, but not to the managerial team as a whole, and the compensation of directors increases with a greater proportion of control group members or their relatives on the board. There was support for the Managerial Power Hypothesis in companies with a lower degree of ownership concentration and for the extraction of private benefits in companies where it is greater.
\end{abstract}

Key words: executive compensation; ownership concentration; corporate governance; agency costs; managerial power hypothesis. 


\section{Introduction}

The Brazilian capital market has experienced extraordinary growth in the past decade. The total amount raised in public offerings of corporate debt and equity securities was US\$12.9 billion in 2001 . These offers amassed a record of US $\$ 98.3$ billion by the end of 2007, just before the spreading of the global financial crisis. This included US $\$ 42.7$ billion in public equity offers, which declined to US $\$ 7.0$ billion by the end of 2012. The total offers of all corporate securities declined to US $\$ 45.1$ billion by the end of 2012. The market value of listed companies in Brazil increased almost sevenfold during the same period, from US $\$ 185.65$ billion in 2001 to US $\$ 1.2$ trillion at the end of 2012, according to data obtained from the Brazilian Securities Commission (CVM, Comissão de Valores Mobiliários, 2010a) and the Central Bank of Brazil (2013).

A reduction in the degree of ownership concentration of listed companies has accompanied this Brazilian market growth in recent years. Some companies emerged that do not have a majority controlling shareholder or group of shareholders with more than half of the votes. Yet, minority control is possible when a shareholder or group of shareholders has de facto control of the company because they have more than half of the voting quorum in shareholder meetings due to shareholder absenteeism, even though they do not own more than half of the voting shares. These shareholders may not declare themselves as controlling shareholders, and as such avoid assuming the legal responsibilities relative to other shareholders that this status entails under Brazilian corporate law (Leal \& Bortolon, 2009; Yokoi, 2012).

The degree of ownership concentration, however, is still high in Brazil. In this article, the expressions low dispersion or high degree of ownership concentration are synonymous, either in reference to total ownership (voting and non-voting shares) or control rights (voting shares only). The decline in the degree of ownership concentration may bring about benefits to investors, such as more liquidity for their shares and reduced losses stemming from majority shareholders' abuse. On the other hand, the lower degree of ownership concentration may aggravate losses arising from the opportunistic behavior by administrators, because it reduces minority shareholders' ability and incentives to monitor them (Gorga, 2009; Leal \& Bortolon, 2009; Olson, 1971). The word administrators refers to both top management and board of directors (BOD) members in this article, following the terminology in Brazilian corporate law.

One of the most fertile arenas for abuse is executive compensation. The information asymmetry between management and shareholders and the difficulty shareholders have in overseeing management acts may lead to an unjustified increase in wages, bonuses, and options paid to the administrators of companies without a controlling shareholder. Excessive top management pay is of great concern in the U.S.A., for example. The literature calls this situation the Managerial Power Hypothesis (Bebchuk \& Fried, 2003; Guthrie, Sokolowsky, \& Wan, 2012). On the other hand, it is also possible that controlling shareholders who act as administrators enjoy excessive compensation (Barontini \& Bozzi, 2011).

This article investigates if the degree of ownership concentration is associated with the compensation of the administrators at Brazilian public companies. Instruction 480 of CVM (2009) mandates disclosure of more data about these companies, including management and director compensation. The recent decline in the degree of ownership concentration and the new disclosure of more detailed information about the compensation of administrators justify this study. Moreover, research relating management and director compensation to the degree of ownership concentration seems to be a gap in the Brazilian literature, as discussed in the literature review section, but is a common subject of inquiry in other jurisdictions (Barontini \& Bozzi, 2011; Bebchuk \& Fried, 2003; Haid \& Yurtoglu, 2006). It is important to understand the nature of the relationship between those variables in Brazil, given the numerous scandals in the US and other countries which have been provoked, for example, by the manner in which management is compensated in dispersed ownership companies. 
The main result supports the hypothesis that firms with a lower degree of ownership concentration pay more to their top managers and directors. The average Chief Executive Officer (CEO) in these companies receives more than double their counterparts in other firms. Still, the compensation of directors that belong to the controlling group, or are a member of their families, is also larger in companies where there is a controlling shareholder or group of shareholders.

The article proceeds with a brief literature review in the second section, followed by the third section that presents the sample, the general form of the estimated models, and the implementation of variables, as well as some descriptive statistics. The fourth section conveys the main results concerning top management and BODs, with the final section offering conclusions.

\section{Literature Review}

A major function of corporations is to allow shareholders to delegate decision-making power in a business to professional management. Delegation allows those who are best positioned to run the company to do so. Nonetheless, this delegation produces agency costs because administrators do not always pursue the best interest of shareholders (Jensen \& Meckling, 1976). Agency costs are the expenses incurred by administrators acting for their own benefit and by shareholders in monitoring them. Agency costs increase as the degree of ownership concentration of company administrators decreases because the interests of shareholders and top managers are now increasingly misaligned (Jensen \& Meckling, 1976). Yet, compensation contracts tied to performance may align the interests of administrators with those of shareholders (Murphy, 1999).

The compensation of administrators, nonetheless, is also an important source of agency costs because they gain greater influence over the decisions related to their own remuneration as the degree of ownership concentration decreases (Bebchuk \& Fried, 2003). A controlling shareholder can contain top management compensation with some ease but this becomes more difficult when the company has no relevant majority shareholder and administrators, thus, at the limit, top managers set their own compensation.

Dispersed shareholders have little incentive to effectively monitor administrators' compensation due to the perverse logic of collective action (Olson, 1971). Any potential benefits of monitoring will be shared with all shareholders while its costs are borne by those shareholders who do the monitoring. Moreover, benefits are not certain, and their expected value is low in view of monitoring's small probability of success, since each individual shareholder has a small share in the equity capital, insufficient in itself to determine decisions in a general shareholders meeting. The logic of collective action is so perverse that shareholders are not even willing to attend the general meetings. Administrators frequently end up determining the outcome of decisions in shareholder meetings, both with regard to their compensation as well as the election of BOD members, by means of public proxy solicitations because shareholder absenteeism is large (Olson, 1971).

International studies that have sought to empirically investigate the relationship between the degree of ownership concentration and administrator compensation generally concluded that companies with a lower degree of ownership concentration pay more to their top managers. Santerre and Neun (1986) analyzed 68 Fortune 500 U.S. companies and concluded that their Herfindahl index for the degree of ownership concentration was inversely related to a company's CEO compensation. They maintain that a lower degree of ownership concentration can lead to an increase of up to $25 \%$ in CEO remuneration. Cyert, Kang, and Kumar (2002) analyzed a sample of 4865 U.S. companies using panel data for the 1992 to 1993 period and also found a strong negative correlation between the ownership of the largest shareholder and a company's CEO remuneration. They assert that doubling the percentage ownership of the largest shareholder reduces top management compensation by $14 \%$, with all else constant. 
Studies about countries where the degree of ownership concentration is higher and the BOD has less power confirm these U.S. results. Barontini and Bozzi (2011) demonstrated that Italian companies with no shareholders holding more than $20 \%$ of equity capital pay more to BOD members and CEOs, based on a sample of 215 firms for the 1995 to 2002 period. The authors conclude that the degree of ownership concentration of the largest shareholder has a strong negative correlation with the remuneration of BOD members and CEOs. They assert, however, that administrators who belong to the family that controls the company earn more than their peers. Haid and Yurtoglu (2006) reached similar conclusions and show that executive compensation falls by $18 \%$ when the largest shareholder ownership increases from $34 \%$ to $78 \%$ for a sample of 400 German companies in the period between 1987 and 2003.

The ownership structure of companies and administrator compensation has been the subject of descriptive studies and surveys in Brazil, but there seems to be a gap with respect to published academic articles specifically detailing the relationship between these two topics; addressing, in particular, BOD and top management compensation separately. There are descriptive studies that have reported on the extreme degree of ownership concentration that prevailed until recently (Aldrighi \& Mazzer, 2005, 2007; Leal, Carvalhal-da-Silva, \& Valadares, 2002; among others) and the decline in the degree of ownership concentration in Brazilian companies in recent years (Canellas \& Leal, 2009; Gorga, 2009; Sternberg, Leal, \& Bortolon, 2011), while others have linked ownership structure to performance or market value of a company (Leal \& Bortolon, 2009; Leal \& Carvalhal-da-Silva, 2006; Okimura, Silveira, \& Rocha, 2007).

A Brazilian Institute of Corporate Governance study describes the compensation of administrators in Brazil and notes that there are companies that still pay symbolic compensation to BOD members and that the percentage of stock-based compensation is low compared to other major economies (Instituto Brasileiro de Governança Corporativa [IBGC], 2011). Other Brazilian studies investigate the relationship between the announcement of stock options and companies' market values (Perobelli, Lopes, \& Silveira, 2012; Santos \& Perobelli, 2009) and the determinants of voluntary disclosure of stock option plans (Schiehll, Terra, \& Victor, in press).

Funchal and Terra (2007) related executive compensation in Latin America to the performance and corporate governance (CG) of companies. The authors found no statistically significant relationship between CEO remuneration and the degree of ownership concentration of the three largest shareholders, although this specific relationship was not the focus of their study. They included only 28 Brazilian companies in a sample of 79 Latin American firms in 2002. Their analysis precedes the aforementioned decline in the degree of ownership concentration and the introduction of Instruction CVM 480 in 2009, which substantially increased the transparency of administrator compensation at Brazilian listed companies. Victor, Carvalho, Funchal, and Terra (2010) offer a comparative analysis of the evolution of management compensation disclosure in Brazil and the U.S.A.

Sousa and Esperança (2012) analyzed 59 companies that made up the Ibovespa index in 2009 and concluded that there was a significant and negative relationship between the degree of ownership concentration and the average total compensation of top management, as well as the proportion of its variable components. Companies controlled by families paid more to top management and the larger ones displayed greater ratios of variable compensation. The authors did not examine other measures of top management compensation, BOD compensation, and did not use the Formulário de Referência (FR - the Reference Form), which is the most comprehensive and authoritative source of information for Brazilian traded companies, introduced by Instruction CVM 480 in 2009. They employed data sources such as the Bolsa de Valores, Mercadorias e Futuros (BM\&FBovespa - the Brazilian Securities, Commodities, and Futures Exchange), complemented by others that may not encompass all available information or details contained in the FR.

Shareholders have various mechanisms to contain abuse by administrators in Brazil, especially in companies with a lower degree of ownership concentration. Shareholders, and not the BOD, are responsible for annually fixing the maximum compensation to be paid to administrators (Lei n. 6404, 1976, art. 152). In addition, shareholders representing $5 \%$ or more of the equity capital may convene a 
general shareholders meeting, which is an exclusive BOD competence in many countries (Lei n. 6404, 1976, art. 123, sole paragraph, item d). Moreover, shareholders representing $0.5 \%$ of the equity capital may include proposals and candidates in public proxy solicitations made by administrators and demand that the company refund expenses incurred with their proxy solicitations, if the company does not have a free-access electronic proxy system (Instruction CVM 481, 2009).

The question is whether these rights are sufficient to overcome the information asymmetry and perverse logic of collective action in companies with a low degree of ownership concentration. It is of no avail that laws and regulations ensure rights to shareholders if they do not use them, due to lack of information or perverse economic incentives. Administrators will have great leeway in setting their own compensation, with the associated risks, if this happens. Dutra and Saito (2002), for instance, concluded that minority shareholders rarely used the cumulative voting right, which would more easily allow the election of their representatives to the BOD (Lei n. 6404, art. 141).

\section{Methodology}

\section{Data and sample}

Instruction CVM 480 (2009) required that public companies annually disclose via the FR the total remuneration of top management and the BOD, including wages, bonuses, benefits, and stockbased compensation, such as stock options. It also demanded that companies disclose and regularly update the FR regarding their ownership structure, identifying who are their controlling shareholders, as well as those that hold 5\% or more of any stock class, down to the level of an individual, the state, or organizations whose owners must remain anonymous by law, such as the ultimate beneficiaries of some institutional investors or the shareholders of companies headquartered in certain countries.

The FR supplied data on compensation and the ownership structure of 587 BM\&FBovespa listed companies in 2009, including the organized over-the-counter market. We excluded companies that listed through Brazilian Depository Receipts (BDR), securitizers, and those that only issued debt securities, bringing the total down to 513. Several companies merged before the release of the FR, failed to disclose information relevant to this study, or disclosed either the compensation of administrators or the ownership structure inadequately or inconsistently. We excluded these companies from the sample as well.

The final sample comprises 315 companies and includes financial and compensation information for 2009. The ownership data comes from the FR relative to 2009, released in 2010. Some companies disclosed their ownership structure relative to 2010 in that FR and we tried to detect and correct for material changes that occurred between 2009 and 2010. We collected company financial information for the 2008 fiscal year to compute lagged performance variables. We note, finally, that we did not execute any procedures to detect and correct for sample selection bias. Thus, we do not infer upon the causal nature of any relationship because the sample may not be random.

\section{Model and variables}

Equation 1 depicts the general form of the cross-sectional model for 2009. The Appendix provides definitions of the variables used in each version of the general model.

$$
\begin{aligned}
& \ln (\text { Comp })=\alpha+\beta_{1}(\text { Own })+\beta_{2}(\text { CFOR })+\beta_{3}(\mathrm{CST})+\beta_{4}(\mathrm{CFAM})+\beta_{5}(\mathrm{NFM} \% \text { or } \\
& \mathrm{NFB} \%)+\beta_{6} \ln (\mathrm{TA})+\beta_{7}(\mathrm{ROA} 09)+\beta_{8}(\mathrm{ROA} 08)+\beta_{9}(\mathrm{~N} 2 \mathrm{NM})+\varepsilon
\end{aligned}
$$

Comp is one of the five measures for the value of compensation of company administrators defined in the Appendix, according to the operational version of the model represented by Equation 1: total top management compensation (TMC), average top management compensation (AMC); 
maximum top management compensation (MMC); total BOD compensation (TBC) or average BOD compensation $(\mathrm{ABC})$. In any case, these variables include all values required by Instruction CVM 480 (2009): wages or honoraria; direct and indirect benefits; bonuses; profit sharing; fees; postemployment benefits; severance pay and benefits; and stock-based compensation, including stock options.

Instruction CVM 480 (2009) requires that the fair value of stock options on the grant date derives from the market value of the company, if available, or an estimate produced by a generally accepted financial-economic valuation model, in accordance with the norms issued by the International Accounting Standards Board (IASB).

The objective of this study is to check whether there is a relationship between the variables that represent the degree of ownership concentration, considering both voting shares (control rights) and all shares (ownership or cash flow rights), and the compensation of company administrators. Therefore, the degree of ownership concentration variable set $(O w n)$ contains the variables of interest on the right side of the model represented by Equation 1. The international literature on top management compensation uses various measures for the degree of ownership concentration, such as the voting or total equity stake of the largest shareholder and Herfindahl concentration indexes (Barontini \& Bozzi, 2011; Haid \& Yurtoglu, 2006; Santerre \& Neun, 1986; Sousa \& Esperança, 2012).

Own is a set of operational variables that measures the degree of ownership concentration of the larger shareholders in the total or voting equity capital (T1, T1V, T5, T5V, TG, TGV, H5, and H5V), as defined in the Appendix. They are used one at a time, and not jointly, in the various versions estimated for the general model represented by Equation 1. Finally, Own also features CMIN, a binary variable that takes the value 1 if there is no shareholder with $50 \%$ or more of the voting shares.

Relevant shareholders themselves or their family members often act as company administrators due to the high degree of ownership concentration in Brazilian companies. A control variable shall account for this because it is possible that these administrators are better paid than others (Sousa \& Esperança, 2012). The participation of relevant shareholders or their family members as company administrators may be measured both by the number or proportion of relevant shareholders and family members in top management (NFM or NFM\%, respectively, when the dependent variable regards the compensation of top management) or the BOD (NFB or NFB\%, respectively, when analyzing BOD compensation).

CFAM is a dummy variable that indicates whether or not there is a family controlling shareholder. We also included dummy variables indicating whether a foreign entity (CFOR) or the state (CST) are shareholders with over $50 \%$ of the votes. The Appendix provides more details.

Other variables control for the association of some company characteristics with compensation. The literature on executive compensation suggests a strong association between company size and top management remuneration, since larger companies require a greater number of more capable administrators (Baker, Jensen, \& Murphy, 1988; Rosen, 1982). Net revenues and total assets are common company size measures in the literature. This study employed the natural logarithm of total assets (TA), defined in the Appendix, as the size variable in Equation 1, following other Brazilian studies, such as Silveira, Leal, Carvalhal-da-Silva, and Barros (2010) and Leal and Carvalhal-da-Silva (2007).

There are several potential measures of company performance, such as return on assets, return on equity, profit margins, or stock return. The literature suggests that there should be an association between the administrator compensation and company performance, even though empirical tests suggest that it may not be very strong (Bebchuk \& Fried, 2004; Murphy, 1985). This study used the return on assets on two separate dates, 2009 (ROA09) and 2008 (ROA08), to measure performance because the stock of some companies display low liquidity, rendering the computation of a reliable average stock return difficult (Leal \& Carvalhal-da-Silva, 2007; Silveira, Leal, Carvalhal-da-Silva, \& Barros, 2010). The option for the average stock return to represent performance would require a 
criterion of minimum liquidity, such as having a market price for a certain number of days in the month, and could lead to a greater number of company exclusions from the sample, justifying our preference for using return on assets. ROA08 and ROA09 are defined in the Appendix.

The compensation of a company's administrators may be associated to the quality of its CG practices (Bebchuk \& Fried, 2004; Cyert, Kang, \& Kumar, 2002; Funchal \& Terra, 2007). To the extent that better CG practices increase transparency and investor protection, they may contribute to containing the remuneration of administrators. Following Silveira et al. (2010), we used a dummy variable indicating listing in the Level 2 or Novo Mercado premium trading segments of BM\&FBovespa (N2NM) in a final set of tests. The premium trading segments require many additional CG and transparency practices that are not mandated by law. The main difference between Level 2 and Novo Mercado is that the latter does not allow the issuance of non-voting shares.

The analysis of the proposed model was carried out for nine operational versions that take into account the inclusion, one at a time, of the nine measures of ownership concentration (T1, T1V, T5, T5V, TG, TGV, H5, H5V, and CMIN, all defined in Appendix). Naturally, these variables are highly correlated with each other and it would not be advisable to jointly include them in a single model, as Table 2 will show.

\section{Descriptive statistics}

Table 1 shows the main characteristics of the non-binary variables in the sample. Figures are in Brazilian real (R\$). The average R $\$$ to US dollars (US\$) exchange rate in 2009 was 2.00 . The total management compensation average (median) was about $\mathrm{R} \$ 1$ million per year $(\mathrm{R} \$ 630,000)$, or $\mathrm{R} \$ 83,000$ per month in 2009 , with a high standard deviation. BOD members' compensation is much lower, with an average (median) of $\mathrm{R} \$ 178,000(\mathrm{R} \$ 73,000)$ per year, or $\mathrm{R} \$ 15,000$ per month.

The ownership structure of companies remains very concentrated because the largest shareholder holds an average of 50\% of total equity and 59\% of the voting capital. The sum of ownership percentages of company controlling groups reaches an average of $60 \%$ and $70 \%$ of the total and voting equity capital, respectively. The Herfindahl indices of ownership concentration are also high, close to one, when based solely on voting shares. Ownership concentration is also evident given that only 49 companies in the sample display potential minority control; i.e., the largest shareholder does not have more than $50 \%$ of the voting capital, although they may actually exercise de facto control, as illustrated by Yokoi (2012). A total of 266 companies still exhibit majority control by means of an individual shareholder or group of shareholders, often bounded by an agreement.

Families control 124 companies, while foreign entities and the state control 41 and 27 firms, respectively. Relevant shareholders or their relatives are BOD members in 172 and top managers in 104 of the 315 companies in the sample. Brazilian companies display an average of 1.48 relevant shareholders or relatives in the BOD and 0.64 in top management.

Table 2 shows correlations between selected independent variables. The correlations between those that measure the degree of ownership concentration are high and positive. The variable CMIN is equal to 1 when there is no shareholder or group with more than $50 \%$ of the votes, that is, when there is more dispersion, and, of course, is inversely correlated with the other variables that measure the degree of ownership concentration. The correlations between the dummy variable that indicates listing in Level 2 or Novo Mercado of BM\&FBovespa and the variables that measure the degree of ownership concentration are negative and noteworthy. Correlations between the other variables did not show any coefficient worth mentioning. 
Table 1

Descriptive Statistics

\begin{tabular}{|c|c|c|c|c|c|c|}
\hline Variable & Average & Median & SD & Maximum & Minimum & No. Obs. \\
\hline \multicolumn{7}{|c|}{ Variables that measure top management compensation (dependent) } \\
\hline $\mathrm{AMC}(\mathrm{R} \$ 000)$ & 1,013 & 629 & 1,431 & 13,816 & 1 & 315 \\
\hline $\mathrm{MMC}(\mathrm{R} \$ 000)$ & 1,485 & 800 & 2,666 & 29,776 & 1 & 199 \\
\hline $\mathrm{TMC}(\mathrm{R} \$ 000)$ & 6,673 & 2,813 & 14,923 & 169,508 & 5 & 315 \\
\hline \multicolumn{7}{|c|}{ Variables that measure BOD compensation (dependent) } \\
\hline $\mathrm{ABC}(\mathrm{R} \$ 000)$ & 178 & 73 & 341 & 2,777 & 0 & 306 \\
\hline $\mathrm{TBC}(\mathrm{R} \$ 000)$ & 1,247 & 455 & 2,561 & 18,520 & 0 & 306 \\
\hline \multicolumn{7}{|c|}{ Variables that measure the degree of ownership concentration } \\
\hline CMIN & 0.16 & 0.00 & 0.36 & 1.00 & 0.00 & 315 \\
\hline H5 & 0.35 & 0.28 & 0.29 & 1.00 & 0.00 & 315 \\
\hline $\mathrm{H} 5 \mathrm{~V}$ & 0.82 & 1.00 & 0.3 & 1.00 & 0.00 & 315 \\
\hline $\mathrm{T} 1(\%)$ & 50 & 49 & 27 & 100 & 0 & 315 \\
\hline $\mathrm{T} 1 \mathrm{~V}(\%)$ & 59 & 60 & 29 & 100 & 0 & 315 \\
\hline T5 (\%) & 70 & 70 & 22 & 100 & 0 & 315 \\
\hline $\mathrm{T} 5 \mathrm{~V}(\%)$ & 78 & 83 & 22 & 100 & 0 & 315 \\
\hline TG (\%) & 60 & 59 & 26 & 100 & 0 & 315 \\
\hline TGV (\%) & 70 & 71 & 26 & 100 & 0 & 315 \\
\hline
\end{tabular}

Variables about the identity, top management, and BOD participation of relevant shareholders

\begin{tabular}{lcccccc}
\hline CFAM & 0.39 & 0.00 & 0.49 & 1.00 & 0.00 & 315 \\
CFOR & 0.13 & 0.00 & 0.34 & 1.00 & 0.00 & 315 \\
CST & 0.09 & 0.00 & 0.28 & 1.00 & 0.00 & 315 \\
NFB & 1.48 & 1.00 & 1.79 & 9.00 & 0.00 & 315 \\
NFB\% & 0.25 & 0.17 & 0.31 & 1.00 & 0.00 & 306 \\
NFM & 0.64 & 0.00 & 1.10 & 8.00 & 0.00 & 315 \\
NFM\% & 0.15 & 0.00 & 0.26 & 1.00 & 0.00 & 315 \\
\hline Other control variables & & & & & \\
\hline TA (R \$ 000) & $15,408,665$ & $1,505,769$ & $74,557,746$ & $708,549,000$ & 24 & 315 \\
N2NM & 0.38 & 0.00 & 0.49 & 1.00 & 0.00 & 315 \\
ROA08 (\%) & 5 & 7 & 31 & 331 & -234 & 315 \\
ROA09 (\%) & -14 & 6 & 338 & 170 & -597 & 315 \\
\hline
\end{tabular}

Note. Variable definitions are in the Appendix. The sample consists of 315 companies, except for MMC that numbers 199 companies because many firms omitted the maximum compensation paid to an individual member of top management, in many cases with the use of injunctions. Nine companies did not inform BOD compensation. SD is the standard deviation. Figures are in Brazilian real (R\$). The average R \$ to US dollars (US\$) exchange rate in 2009 was 2.00. Source: Author computations from data obtained in the Formulários de Referência (FR) (Comissão de Valores Mobiliários. (2010b). Formulário de referência. Retrieved from http://www.cvm.gov.br/port/redir.asp?subpage=outrainformacao) and annual financial statements of public companies (Comissão de Valores Mobiliários. (2010c). Dados econômico-financeiros. Retrieved from http://www.cvm.gov.br/port/redir.asp?subpage=outrainformacao). 
Table 2

\section{Correlations between Selected Variables}

\begin{tabular}{lccccccccc}
\hline \multicolumn{7}{c}{ Panel 1: between variables that measure the degree of ownership concentration and other variables } \\
\hline & CMIN & H5 & H5V & T1 & T1V & T5 & T5V & TG & TGV \\
CFAM & -0.29 & -0.08 & 0.02 & -0.02 & 0.06 & -0.02 & 0.12 & 0.06 & 0.17 \\
CFOR & -0.14 & 0.27 & 0.28 & 0.29 & 0.28 & 0.19 & 0.18 & 0.20 & 0.20 \\
CST & -0.10 & 0.21 & 0.19 & 0.19 & 0.19 & 0.14 & 0.14 & 0.14 & 0.13 \\
Ln(TA) & -0.01 & -0.15 & -0.06 & -0.11 & -0.03 & -0.25 & -0.14 & -0.15 & -0.07 \\
N2NM & 0.35 & -0.37 & -0.48 & -0.35 & -0.45 & -0.39 & -0.52 & -0.36 & -0.51 \\
NFB\% & -0.07 & 0.00 & 0.01 & 0.01 & 0.01 & 0.01 & 0.04 & 0.04 & 0.04 \\
NFM\% & -0.13 & -0.09 & -0.08 & -0.05 & -0.04 & -0.03 & -0.01 & 0.03 & 0.05 \\
ROA08 & 0.02 & -0.13 & -0.11 & -0.13 & -0.10 & -0.03 & -0.02 & -0.12 & -0.10 \\
ROA09 & 0.04 & -0.25 & -0.20 & -0.22 & -0.18 & -0.14 & -0.11 & -0.19 & -0.15 \\
\hline
\end{tabular}

Panel 2: between variables that measure the degree of ownership concentration (below the diagonal) and between other variables (above the diagonal)

\begin{tabular}{|c|c|c|c|c|c|c|c|c|c|}
\hline & CFOR & CST & $\operatorname{Ln}(\mathrm{TA})$ & $\mathrm{N} 2 \mathrm{NM}$ & NFB $\%$ & NFM\% & ROA08 & ROA09 & \\
\hline & -0.31 & -0.25 & 0.47 & -0.09 & 0.03 & 0.47 & -0.12 & 0.00 & CFAM \\
\hline H5 & -0.40 & -0.12 & -0.07 & -0.08 & -0.01 & -0.21 & 0.12 & -0.10 & CFOR \\
\hline $\mathrm{H} 5 \mathrm{~V}$ & -0.52 & 0.78 & 0.22 & 0.22 & -0.18 & -0.18 & 0.00 & 0.04 & CST \\
\hline $\mathrm{T} 1$ & -0.46 & 0.97 & 0.80 & 0.25 & 0.01 & -0.17 & 0.27 & 0.45 & $\operatorname{Ln}(\mathrm{TA})$ \\
\hline $\mathrm{T} 1 \mathrm{~V}$ & -0.58 & 0.76 & 0.97 & 0.82 & -0.01 & -0.15 & 0.05 & 0.12 & N2NM \\
\hline $\mathrm{T} 5$ & -0.48 & 0.78 & 0.61 & 0.76 & 0.59 & -0.02 & 0.03 & 0.00 & NFB $\%$ \\
\hline $\mathrm{T} 5 \mathrm{~V}$ & -0.64 & 0.57 & 0.77 & 0.59 & 0.76 & 0.78 & -0.11 & 0.00 & NFM $\%$ \\
\hline TG & -0.60 & 0.82 & 0.61 & 0.80 & 0.59 & 0.82 & 0.62 & 0.41 & ROA08 \\
\hline \multirow[t]{2}{*}{$\mathrm{TGV}$} & -0.75 & 0.62 & 0.81 & 0.64 & 0.80 & 0.64 & 0.83 & 0.77 & \\
\hline & CMIN & $\mathrm{H} 5$ & $\mathrm{H} 5 \mathrm{~V}$ & $\mathrm{~T} 1$ & $\mathrm{~T} 1 \mathrm{~V}$ & T5 & $\mathrm{T} 5 \mathrm{~V}$ & TG & \\
\hline
\end{tabular}

Note. Variable definitions are in the Appendix. Correlations are Pearson coefficients. Source: Author computations from data obtained in the Formulários de Referência (FR) (Comissão de Valores Mobiliários. (2010b). Formulário de referência. Retrieved from http://www.cvm.gov.br/port/redir.asp?subpage=outrainformacao) and annual financial statements of public companies (Comissão de Valores Mobiliários. (2010c). Dados econômico-financeiros. Retrieved from http://www.cvm.gov.br/port/redir.asp?subpage=outrainformacao).

\section{Results}

The next two sections present the main results for top management and BODs, respectively. The findings support the hypothesis that greater compensation of top management and BODs is associated with a lower degree of ownership concentration and that a larger proportion of BOD members that are relevant shareholders or their relatives is associated to higher BOD compensation. The last section presents an analysis considering company listing in the premium trading segments of BM\&FBovespa. 


\section{Top management compensation}

The natural logarithm of the total top management compensation (TMC) of a company, as defined in the Appendix, is the focus of this section since the results for the other top management compensation variables (AMC and MMC) are similar. Table 3 presents the main results for the selected versions of the general model depicted by Equation 1 that indicate a significant negative correlation between the degree of ownership concentration and TMC. Companies with a higher degree of ownership concentration, considering both total equity and voting shares only, pay less to their top management, ceteris paribus.

The 2008 return on assets (ROA08), the foreign entity and the family controlling shareholder dummies (CFOR and CFAM, respectively) did not show significance in any of the initial estimations and were excluded from the final estimations presented in Table 3. This increased the F-statistic and reduced the heteroscedasticity in the residuals of the final models, but did not significantly change the value of the coefficients compared to those in the initial models. Generally speaking, statistics provided in Table 3 did not detect any serious model specification problems. Note that the result for CFAM contrasts with the findings in Sousa and Esperança (2012) for a sample of 59 companies that comprised the Ibovespa in 2009.

ROA09 was significant in all TMC models at first. Yet, an extreme value of $-597 \%$ for Steel Brasil Participações was responsible for this result. ROA09 was no longer significant and behaved similarly to ROA08 after this extreme value was replaced by the next lowest value in the sample (a process known as winsorization), and the models were estimated again. Thus, ROA09 was excluded from the final specifications displayed in Table 3.

Model 1 for TMC in Table 3 shows that the minority control variable (CMIN) has a statistically and economically significant coefficient, suggesting that companies with no controlling shareholders pay $79 \%$ more to their top managers, ceteris paribus. In other words, top management compensation is greater when no single shareholder or a group bounded by an agreement possess more than $50 \%$ of the voting capital, which denotes the existence a controlling shareholder or group. Minority control may imply that there may be a relevant group of shareholders that actually hold most votes in shareholders meetings considering the usual quorum. They do not possess $50 \%$ or more of the votes and do not assume the responsibilities of a controlling shareholder before the other shareholders, as provided by law, because they do not declare themselves as de facto controlling shareholders. This is a new phenomenon that has been discussed in the business press and derives from the decline in the degree of ownership concentration (Yokoi, 2012).

Models 2 and 3 for TMC in Table 3 show that the degree of total and voting ownership concentration in the hands of the largest shareholder exhibits a high negative correlation with total top management compensation. A $1 \%$ increase in the average of the total (voting) degree of ownership concentration of the largest shareholder is related to a reduction of $0.87 \%(0.78 \%)$ in the average of total top management compensation. Model 4 for TMC confirms the previous results. A $1 \%$ increase in the average total degree of ownership concentration of the five largest shareholders is related to a reduction of $1.81 \%$ in the average of total top management compensation. The models that used the degree of voting ownership concentration of the five largest shareholders (T5V), total and voting degrees of ownership concentration of the largest group of shareholders bound by a voting agreement or whose members belong to the same family (TG or TGV), and the degree of ownership concentration represented by Herfindahl indices (H5 and $\mathrm{H} 5 \mathrm{~V})$ presented similar results and were omitted from Table 3. Complete results are available from the authors.

Interestingly, these results are obtained even in the presence of the effect of state control (CST) because Table 3 shows that Brazilian state-owned companies pay less to their top managers than other companies. It should also be noted that the proportion of relevant shareholders or their relatives in top management positions (NFM\%) does not seem to be associated with total top management compensation. One would expect that relevant shareholders exert their power to ensure a higher compensation when they or their family members occupy top management positions, but there was no 
evidence of that. The size of the company always has a positive and significant correlation with total top management compensation.

The number of top executives may greatly affect the total of top management compensation. Thus, the natural logarithm of the average top management compensation (AMC) replaced TMC as the dependent variable in a set of tests similar to those in Table 3. The results, however, were analogous to those that have already been presented and were omitted. These are available from the authors.

Instruction CVM 480 (2009) requires that public companies disclose the maximum individual compensation paid to top management (MMC) but does not demand the identification of the recipient. In spite of this, many companies did not disclose this information, some supported by injunctions, alleging that disclosure of the maximum compensation actually corresponded to revealing the compensation of the CEO, which would put this professional in great personal risk. This reduced the sample size to 199 companies in the models for this dependent variable. Even so, the results from models with this dependent variable, once again, confirmed the negative correlation between the degree of ownership concentration and top management compensation. A minority-controlled company pays, on average, $104 \%$ more to its CEO than a company with a controlling shareholder or group, a result that is statistically significant. The other results were also similar to those for the total or average top management compensation, but there was an important difference. The dummy variable for family control (CFAM) was marginally significant, suggesting that, on average, a family controlled company pays $43 \%$ more to its CEO than other companies, an evidence consistent with that in Sousa and Esperança (2012). The results for the maximum top management compensation are available from the authors.

Table 3

Total Top Management (TMC) and BOD (TBC) Compensation Models

\begin{tabular}{|c|c|c|c|c|c|c|c|c|}
\hline \multirow{2}{*}{ Variable } & \multicolumn{4}{|c|}{$\ln (T M C)$ Models } & \multicolumn{4}{|c|}{$\ln (T B C)$ Models } \\
\hline & 1 & 2 & 3 & 4 & 1 & 2 & 3 & 4 \\
\hline Constant & $\begin{array}{l}3.10^{*} \\
(3.35)\end{array}$ & $\begin{array}{l}4.03^{*} \\
(4.20)\end{array}$ & $\begin{array}{l}3.87^{*} \\
(3.99)\end{array}$ & $\begin{array}{l}5.54^{*} \\
(6.01)\end{array}$ & $\begin{array}{l}4.64^{*} \\
(6.21)\end{array}$ & $\begin{array}{l}6.25^{*} \\
(7.64)\end{array}$ & $\begin{array}{l}5.63 * \\
(7.37)\end{array}$ & $\begin{array}{c}7.01 * \\
(7.45)\end{array}$ \\
\hline $\ln (\mathrm{TA})$ & $\begin{array}{c}0.55^{*} \\
(12.93)\end{array}$ & $\begin{array}{c}0.53^{*} \\
(12.28)\end{array}$ & $\begin{array}{c}0.54 * \\
(12.44)\end{array}$ & $\begin{array}{c}0.50^{*} \\
(12.10)\end{array}$ & $\begin{array}{c}0.37 * \\
(10.82)\end{array}$ & $\begin{array}{l}0.35^{*} \\
(9.59)\end{array}$ & $\begin{array}{c}0.36^{*} \\
(10.28)\end{array}$ & $\begin{array}{l}0.33^{*} \\
(9.10)\end{array}$ \\
\hline NFM $\%$ or NFB $\%$ & $\begin{array}{c}-0.39 \\
(-1.06)\end{array}$ & $\begin{array}{c}-0.61 \\
(-1.67)\end{array}$ & $\begin{array}{c}-0.57 \\
(-1.56)\end{array}$ & $\begin{array}{c}-0.64 \\
(-1.81)\end{array}$ & $\begin{array}{l}1.24^{*} \\
(3.35)\end{array}$ & $\begin{array}{l}0.97 * \\
(3.35)\end{array}$ & $\begin{array}{l}1.06^{*} \\
(3.50)\end{array}$ & $\begin{array}{c}0.99 * \\
(3.28)\end{array}$ \\
\hline CST & $\begin{array}{l}-1.35^{*} \\
(-4.54)\end{array}$ & $\begin{array}{l}-1.31 * \\
(-4.30)\end{array}$ & $\begin{array}{l}-1.33 * \\
(-4.35)\end{array}$ & $\begin{array}{l}-1.22 * \\
(-4.20)\end{array}$ & - & - & - & - \\
\hline CMIN & $\begin{array}{l}0.79 * \\
(4.63)\end{array}$ & - & - & - & $\begin{array}{l}0.80^{*} \\
(4.93)\end{array}$ & - & - & - \\
\hline $\mathrm{T} 1$ & - & $\begin{array}{l}-0.87 * \\
(-2.57)\end{array}$ & - & - & - & $\begin{array}{l}-1.73^{*} \\
(-4.94)\end{array}$ & - & - \\
\hline $\mathrm{T} 1 \mathrm{~V}$ & - & - & $\begin{array}{l}-0.78^{*} \\
(-2.71)\end{array}$ & - & - & - & $\begin{array}{l}-1.15^{*} \\
(-3.78)\end{array}$ & - \\
\hline T5 & - & - & - & $\begin{array}{l}-1.81 * \\
(-4.57)\end{array}$ & - & - & - & $\begin{array}{l}-1.75^{*} \\
(-4.01)\end{array}$ \\
\hline
\end{tabular}


Table 3 (continued)

\begin{tabular}{|c|c|c|c|c|c|c|c|c|}
\hline \multirow{2}{*}{ Variable } & \multicolumn{4}{|c|}{$\ln (T M C)$ Models } & \multicolumn{4}{|c|}{$\ln (T B C)$ Models } \\
\hline & 1 & 2 & 3 & 4 & 1 & 2 & 3 & 4 \\
\hline Adj. $R^{2}$ & 0.48 & 0.47 & 0.47 & 0.49 & 0.28 & 0.32 & 0.29 & 0.30 \\
\hline $\mathrm{F}$ & $71.66^{*}$ & $69.71 *$ & $69.48^{*}$ & $76.60^{*}$ & $39.39 *$ & $46.82 *$ & $40.77 *$ & $42.72 *$ \\
\hline DW & 1.89 & 1.94 & 1.94 & 1.94 & 1.87 & 1.88 & 1.88 & 1.85 \\
\hline RESET F & 0.36 & 0.51 & 0.32 & 3.48 & 0.62 & 1.65 & 1.07 & 0.17 \\
\hline $\mathrm{BPG}$ & $2.80 *$ & $2.78 *$ & $2.53 *$ & $3.53 *$ & 1.71 & 1.25 & $3.46^{*}$ & 0.21 \\
\hline
\end{tabular}

Note. Variable definitions are in the Appendix. The models were estimated by ordinary least squares using White's heteroscedasticity consistent standard errors and covariances. There are 315 observations for $T M C$ and 291 observations for $T B C$ because 9 companies did not inform their BOD compensation and 15 informed a null BOD compensation and were deleted from the sample. $N F M \%$ was used in the $\ln (T M C)$ models and $N F B \%$ in the $\ln (T B C)$ models. The model estimated for TMC was $\ln (T M C)=\alpha+\beta_{1} \ln (T A)+\beta_{2}(N F M \%)+\beta_{3}(C S T)+\beta_{4}(O w n)+\varepsilon$, whereas Own are the variables CMIN, T1, $T 1 \mathrm{~V}$, and $T 5$, that measure the total equity or voting shares degree of ownership concentration for models $1,2,3$, and 4 , respectively. The model estimated for $T B C$ was $\ln (T B C)=\alpha++\beta_{l} \ln (T A)+\beta_{2}(N F B \%)+\beta_{3}(O w n)+\varepsilon$, whereas $O w n$ are the same variables used to estimate $T M C$. The numbers in parenthesis are the t-statistics for the coefficients. BPG is the Fstatistics of the Breusch-Pagan-Godfrey test for the null hypothesis of homoscedasticity in the residuals. "RESET F" is the "Regression Specification Error Test" using omitted squared variables that tests for omitted variables, inadequate variable functional form, and the existence of correlation between the independent variables and the residuals. Its null hypothesis is that the coefficient of the introduced squared variable, which may have been omitted, is null, and it is rejected when $F$ is significant. DW is the Durbin-Watson statistics. Variance inflation factors tests for each coefficient do not suggest multicollinearity problems in the models and were omitted. Source: Author computations from data obtained in the Formulários de Referência (FR) (Comissão de Valores Mobiliários. (2010b). Formulário de referência. Retrieved from $\mathrm{http} / /$ www.cvm.gov.br/port/redir.asp?subpage=outrainformacao) and annual financial statements of public companies (Comissão de Valores Mobiliários. (2010c). Dados econômico-financeiros. Retrieved from http://www.cvm.gov.br/port/redir.asp?subpage=outrainformacao).

${ }^{*}$ indicates statistical significance at the $5 \%$ level.

\section{BOD compensation}

Unlike management, BOD members (directors) are chosen directly by shareholders and usually have closer ties with them. In the sample, for example, 172 companies have relevant shareholders or their relatives on the BOD, but this number drops to 104 in top management. Directors are not responsible for the day-to-day management of the company. They must set the general guidelines of the business and oversee its management.

Nevertheless, the results depicted in Table 3 confirm the expected relationship between the degree of ownership concentration and BOD compensation. BOD compensation increases as the degree of ownership concentration declines. The total BOD compensation (TBC) models in Table 3 employ a smaller sample of 291 companies because 15 companies do not pay their directors and 9 did not disclose their BOD compensation, rendering it impossible to take the natural logarithm of their TBC.

The final model estimates for $T B C$ in Table 3 do not include ROA08, ROA09, and the dummies for foreign entity (CFOR), family (CFAM), and state (CST) control because they were not significant in any of the initial model estimations. Their exclusion improved the specification statistics of the models but did not change the value of the reported coefficients significantly, as in the models for TMC.

Model 1 for $T B C$ in Table 3 has minority control (CMIN) as the main variable of interest. It confirms a positive and significant correlation between CMIN and TBC. Companies with no controlling shareholders pay, ceteris paribus, $80 \%$ more, on average, to their BOD. Model 1 also shows that companies that have relevant shareholders or their relatives as BOD members pay significantly more to their BOD. On average, total BOD compensation rises 1.24 times with the proportion of relevant shareholders or their family members that sit on the BOD. 
These results persist, generally speaking, even when one considers the other variables that measure the degree of ownership concentration. Models 2 and 3 for TBC in Table 3 suggest that a 1\% increase in the degree of ownership concentration of the largest shareholder, total and voting, is associated with a reduction of $1.73 \%$ and $1.15 \%$ in total BOD compensation, respectively. Moreover, a greater proportion of relevant shareholders or their relatives on the BOD raises its total compensation. The $T B C$ model 4 in Table 3 presents similar results for the five largest shareholders. The other models for $T B C$, using the degree of ownership concentration measures not depicted in Table 3 (T5V, TG, TGV, H5, and H5V) showed similar results. All models were also estimated with the natural logarithm of the average BOD compensation (ABC) as the dependent variable and their results were alike those in Table 3. The omitted tests are available from the authors.

\section{Corporate governance practices}

It may be that companies that supposedly have better CG practices present distinct characteristics with regards to the remuneration of administrators. Companies with a lower degree of ownership concentration tend to trade in Level 2 or Novo Mercado because only $20 \%$ of the companies without a controlling shareholder or group of shareholders do not list in those segments of the market. This suggests that better CG practices may be positively correlated with the degree of ownership concentration. Companies with a lower degree of ownership concentration may need to have a more intense relationship with investors than companies with more concentrated ownership and, consequently, possess a better structured BOD and disclose more information.

Durnev and Kim (2005), for example, formulated a theoretical model that attained empirical support stating that a lower degree of ownership concentration causes companies to adopt better CG practices. Moreover, as emphasized in Silveira et al. (2010), there is probably an endogeneity problem due to reverse causality between the quality of $\mathrm{CG}$ practices and the degree of ownership concentration, since a decrease in the latter may increase the quality of CG, which, in turn, may contribute to the degree of ownership concentration decline.

Table 4

Level 2 or Novo Mercado Listing and Total Top Management Compensation

\begin{tabular}{lcc}
\hline \multirow{2}{*}{ Variable } & \multicolumn{1}{c}{ Models } \\
\cline { 2 - 3 } Constant & $\mathbf{1}$ & $\mathbf{2}$ \\
& $3.97^{*}$ & $5.38^{*}$ \\
& $(4.48)$ & $(5.99)$ \\
Ln(TA) & $0.49^{*}$ & $0.47^{*}$ \\
& $(11.76)$ & $(11.43)$ \\
NFM\% & -0.30 & -0.40 \\
& $(-0.88)$ & $(-1.17)$ \\
CST & $-1.08^{*}$ & $-0.98^{*}$ \\
& $(-3.53)$ & $(-3.26)$ \\
N2NM & $0.99^{*}$ & $0.80^{*}$ \\
& $(6.27)$ & $(4.73)$ \\
T5 & - & $-1.24 *$ \\
& & $(-3.00)$ \\
\hline
\end{tabular}


Table 4 (continued)

\begin{tabular}{lcc}
\hline & \multicolumn{2}{c}{ Models } \\
\cline { 2 - 3 } Variable & $\mathbf{1}$ & $\mathbf{2}$ \\
\hline Adj. $\mathrm{R}^{2}$ & 0.51 & 0.52 \\
F & $81.32^{*}$ & $68.96^{*}$ \\
DW & 1.93 & 1.94 \\
RESET F & 1.22 & 1.67 \\
BPG & $4.63^{*}$ & $5.42^{*}$ \\
\hline
\end{tabular}

Note. Variable definitions are in the Appendix. The models were estimated by ordinary least squares using White's heteroscedasticity consistent standard errors and covariances. There are 315 observations. The dependent variable is the natural logarithm of the total top management compensation (TMC). Model 2 was estimated as $\ln (T M C)=\alpha+\beta_{l} \ln (T A)+$ $\beta_{2}(N F M \%)+\beta_{3}(C S T)+\beta_{4}(N 2 N M)+\beta_{5}(T 5)+\varepsilon . T 5$ was omitted in model 1 . The numbers in parenthesis are the t-statistics for the coefficients. See the note in Table 3 for information about the DW, RESET F, and BPG statistics. Variance inflation factors tests for each coefficient do not suggest multicollinearity problems in the models and were omitted. Source: Author computations from data obtained in the Formulários de Referência (FR) (Comissão de Valores Mobiliários. (2010b). Formulário de referência. Retrieved from http://www.cvm.gov.br/port/redir.asp?subpage=outrainformacao) and annual financial statements of public companies (Comissão de Valores Mobiliários. (2010c). Dados econômico-financeiros. Retrieved from http://www.cvm.gov.br/port/redir.asp?subpage=outrainformacao).

* indicates statistical significance at the $5 \%$ level.

Table 4 shows two versions of model 4 for TMC in Table 3 that include a dummy variable that represents good CG practices (N2NM) and indicates that the company trades in one of the premium segments, Level 2 or Novo Mercado, of BM\&FBovespa, as suggested by Silveira et al. (2010). Model 1 in Table 4 does not include a degree of ownership concentration variable and Model 2 adds the total degree of ownership concentration of the five largest shareholders (T5), which was the degree of ownership concentration variable that obtained the largest coefficient in the regressions of Table 3.

The results indicate that companies that belong to Level 2 or Novo Mercado pay more to their top management. T5 in Model 2 maintains the expected negative sign while N2NM preserves the positive coefficient attained in Model 1, both significant, suggesting that companies with a lower degree of ownership concentration and that trade in Level 2 or Novo Mercado pay more to their top managers and, thus, that the Managerial Power Hypothesis may have merit in Brazil.

In principle, there is no reason to suspect that good CG practices raise the compensation of administrators and, therefore, the evidence from Model 1 may simply suggest that companies with a lower degree of ownership concentration, which tend to pay more to top management, often join Level 2 and Novo Mercado, possibly to signal their disposition to have better CG practices, as Durnev and Kim (2005) predicted.

\section{Conclusions}

The Managerial Power Hypothesis suggests that companies with a lower degree of ownership concentration tend to pay their top managers more. Dispersed shareholders have less incentive and find it harder to control the compensation of top management and directors (Bebchuk \& Fried, 2003). Admittedly, on the other hand, relevant shareholders who hold top management or board positions also have incentives to abuse them. Unless they hold all company shares, they can increase their pay, as they bear only part of the cost and receive the benefits in full (Barontini \& Bozzi, 2011).

This article analyzed the relationship between the degree of ownership concentration and the remuneration of top managers and board of directors members separately, which is a gap in the national literature, and presents empirical evidence consistent with these theoretical observations. The 
results indicate that companies that do not have a controlling shareholder or group of shareholders pay, on average, $79 \%$ more to top management and $80 \%$ more to their board. The remuneration of the CEO of these companies is more than double than in other companies.

The results also suggest that, on average, an increase of $1 \%$ in the percentage share of the votes of the five largest shareholders leads to a reduction of the total top management and board of directors compensation of $1.81 \%$ and $1.75 \%$, respectively.

There is evidence that relevant shareholders or their family members who hold board positions earn more. On average, the total board of directors compensation rises approximately $1 \%$ for each $1 \%$ increase in the percentage participation of relevant shareholders or their family members in the board. Family-controlled companies also pay $43 \%$ more to their CEO than the others, on average, although there was no evidence that they pay more to all top managers.

Though significant, the difference in pay related to the presence of controlling shareholders or their relatives in the board of directors seems less important economically than that associated with the degree of ownership concentration. Indeed, the average (median) number of relevant shareholders or their family members on the board of directors is only 1.48 (1) per company and the average annual remuneration of board members in Brazil $(\mathrm{R} \$ 178,000)$ is much lower than that of top managers $(\mathrm{R} \$ 1$ million).

The evidence in this article is consistent with that in the unpublished work of Sousa and Esperança (2012), who analyzed a sample of 59 companies included in the Ibovespa index in 2009, employing data from sources different than ours. These authors analyzed the average top management compensation and also reveal a negative relationship with a measure of the degree of ownership concentration, as well as a positive relationship with family control. They did not examine other measures of top management compensation or the remuneration of the board of directors.

Investors are facing a new challenge in Brazil. They must monitor the remuneration of top management and directors of companies with a lower degree of ownership concentration from now on, as well as the conduct of controlling shareholders in companies with a greater degree of ownership concentration, something that supposedly they were already used to. Monitoring is important to control the amount of compensation, its structure, and the incentives entailed.

The insufficient and perhaps perverse incentives created by defective compensation mechanisms are possibly more pernicious than the actual increase in compensation spending (Bebchuk, Fried, \& Walker, 2002). Indeed, incorrectly structured compensation programs fail to create the necessary incentives for administrators to work on behalf of shareholders. In addition, administrators have an interest in camouflaging their actual remuneration when they opt for less transparent programs that generate perverse incentives, such as variable compensation tied to irrelevant metrics, option plans that pay out according to gains arising from changes in the general stock market price level, or equity grants that make them focus exclusively on short-term results (Bebchuk \& Fried, 2004).

The values potentially involved are not at all negligible. In 2000, the CEOs of US companies earned, on average, $7.89 \%$ of the profits of the companies they managed (Balsam, 2002). We estimated the percentage of the average maximum top management compensation relative to the average net income of the companies in our sample to be $0.32 \%$. Even though the amounts paid to Brazilian top managers and directors are not near the levels prevailing in the U.S.A. yet, it is possible that they move in that direction, especially if the degree of ownership concentration continues to decrease.

The limitations of this study are opportunities for future research. In particular, we could not adequately address self-selection with a sample limited to one year and, therefore, we cannot make statements about causality. Subsequent investigations may use a panel of a few years and deal rigorously with the problems of self-selection in order to check for causal relationships, in addition to the correlations that we unveiled, by employing econometric methods as the panel procedure known as Generalized Method of Moments system estimator (GMM-sys) used in Silveira et al. (2010), with a 
tutorial offered by Mileva (2007), or a system of three-stage least squares structural equations and a fixed effects panel, if appropriate, used by Leal and Carvalhal-da-Silva (2007). Using data from years following 2009 may also clarify whether the results were influenced by the global financial crisis. Moreover, the constants of all models are significant, suggesting that there may be omitted variables and that new studies should seek additional determinants of the compensation of top managers and directors.

\section{References}

Aldrighi, D. M., \& Mazzer, R., Neto (2005). Estrutura de propriedade e de controle das empresas de capital aberto no Brasil. Revista de Economia Política, 25(2), 115-137. doi: 10.1590/S010131572005000200009

Aldrighi, D. M., \& Mazzer, R., Neto (2007). Evidências sobre as estruturas de propriedade de capital e de voto das empresas de capital aberto no Brasil. Revista Brasileira de Economia, 61(2), 129152. doi: 10.1590/S0034-71402007000200001

Baker, G. P., Jensen, M., \& Murphy, K. (1988) Compensation and incentives: practice vs. theory. The Journal of Finance, 43(3), 593-616. doi: 10.1111/j.1540-6261.1988.tb04593.x

Balsam, S. (2002). An introduction to executive compensation. London: Academic Press.

Barontini, R., \& Bozzi, S. (2011). Board compensation and ownership structure: empirical evidence for Italian listed companies. Journal of Management and Governance, 15(1), 59-89. doi: 10.1007/s10997-009-9118-5

Bebchuk, L. A., \& Fried, J. M. (2003). Executive compensation as an agency problem. Journal of Economic Perspectives, 17(3), 71-92. doi: 10.1257/089533003769204362

Bebchuk, L. A., \& Fried, J. M. (2004). Pay without performance: the unfulfilled promise of executive compensation. Cambridge: Harvard University Press.

Bebchuk, L. A., Fried, J. M., \& Walker, D. (2002). Managerial power and rent extraction in the design of executive compensation. University of Chicago Law Review, 69(3), 751-846.

Canellas, T. C., \& Leal, R. P. C. (2009). Evolução da estrutura de controle das empresas listadas na Bovespa entre 2004 e 2006. In M. Chauvel \& M. Cohen (Eds.), Ética, sustentabilidade e sociedade (pp. 49-68). São Paulo: Mauad.

Central Bank of Brazil. (2013). Taxas de câmbio. Retrieved from http://www4.bcb.gov.br/pec/taxas/port/ptaxnpesq.asp?id=txcotacao

Comissão de Valores Mobiliários. (2010c). Dados econômico-financeiros. Retrieved from http://www.cvm.gov.br/port/redir.asp?subpage=outrainformacao

Comissão de Valores Mobiliários. (2010b). Formulário de referência. Retrieved from http://www.cvm.gov.br/port/redir.asp?subpage=outrainformacao

Comissão de Valores Mobiliários. (2010a). Informativo CVM. Retrived from http://www.cvm.gov.br/port/redir.asp?subpage=informativo

Cyert, R. M., Kang, S.-H., \& Kumar, P. (2002). Corporate governance, takeovers, and topmanagement compensation: theory and evidence. Management Science, 48(4), 453-469. doi: 10.1287/mnsc.48.4.453.205 
Durnev, A., \& Kim, E. H. (2005). To steal or not to steal: firm attributes, legal environment, and valuation. The Journal of Finance, 60(3), 1461-1493. doi: 10.1111/j.1540-6261.2005.00767.x

Dutra, M. G. L., \& Saito, R. (2002). Conselhos de administração: análise de sua composição em um conjunto de companhias abertas brasileiras. Revista de Administração Contemporânea, 6(2), 927. doi: 10.1590/S1415-65552002000200003

Funchal, J. A., \& Terra, P. R. S. (2007, July). Executive compensation, firm performance, and corporate governance in Latin America. Anais do Encontro Brasileiro de Finanças, São Paulo, SP, Brasil, 6.

Gorga, E. (2009). Changing the paradigm of stock ownership from concentrated towards dispersed ownership? Evidence from Brazil and consequences for emerging countries. Northwestern Journal of International Law \& Business, 29(2), 439-554.

Guthrie, K., Sokolowsky, J., \& Wan, K.-M. (2012). CEO compensation and board structure revisited. The Journal of Finance, 67(3), 1149-1168. doi: 10.1111/j.1540-6261.2012.01744.x

Haid, A., \& Yurtoglu, B. B. (2006). Ownership structure and executive compensation in Germany. Retrieved from http://ssrn.com/abstract=948926

Instituto Brasileiro de Governança Corporativa. (2011). Remuneração dos administradores. São Paulo: Autor.

Instrução CVM n. 480, de 7 de dezembro de 2009. (2009). Dispõe sobre o registro de emissores de valores mobiliários admitidos à negociação em mercados regulamentados de valores mobiliários. Diário Oficial da União. Brasília, DF: Imprensa Nacional.

Instrução CVM n. 481, de 17 de dezembro de 2009. (2009). Dispõe sobre informações e pedidos públicos de procuração para exercício do direito de voto em assembléias de acionistas. Diário Oficial da União. Brasília, DF: Imprensa Nacional.

Jensen, M., \& Meckling, W. (1976). Theory of the firm: managerial behavior, agency costs, and ownership structure. Journal of Financial Economics, 3(4), 305-360. doi: 10.1016/0304405X(76)90026-X

Leal, R. P. C., \& Bortolon, P. M. (2009). Controle compartilhado: impactos sobre o valor da firma. In Instituto Brasileiro de Governança Corporativa (Orgs.), Governança corporativa - estrutura de controles societários (pp. 125-137). São Paulo: Saint Paul Editora.

Leal, R. P. C., \& Carvalhal-da-Silva, A. L. (2006). Controlling shareholders and corporate valuation in Brazil. Corporate Ownership and Control, 3(2), 137-141.

Leal, R. P. C., \& Carvalhal-da-Silva, A. L. (2007). Corporate governance and value in Brazil (and in Chile). In A. Chong \& F. Lopez-De-Silanes (Eds.), Investor protection and corporate governance: firm level evidence across Latin America (pp. 213-287). Palo Alto: Stanford University Press.

Leal, R. P. C., Carvalhal-da-Silva, A. L., \& Valadares, S. (2002). Estrutura de controle e propriedade das companhias brasileiras de capital aberto. Revista de Administração Contemporânea, 6(1), 7 18. doi: 10.1590/S1415-65552002000100002

Lei n. 6.404, de 15 de dezembro de 1976. (1976). Dispõe sobre as sociedades por ações. Diário Oficial da União. Brasília, DF: Imprensa Nacional.

Mileva, E. (2007). Using Arellano-Bond dynamic panel GMM estimators in Stata. Retrieved from http://www.fordham.edu/economics/mcleod/Elitz-UsingArellano-BondGMMEstimators.pdf 
Murphy, K. (1985). Corporate performance and managerial remuneration: an empirical analysis. Journal of Accounting and Economics, 7(1-3), 11-42. doi: 10.1016/0165-4101(85)90026-6

Murphy, K. (1999). Executive compensation. In O. Ashenfelter \& D. Card (Eds.), Handbook of labor economics (pp. 2485-2563). North Holland: Elsevier.

Okimura, R. T., Silveira, A. M. da, \& Rocha, K. C. (2007). Estrutura de propriedade e desempenho corporativo no Brasil. RAC-Eletrônica, 1(1), 119-135. Recuperado de http://www.anpad.org.br/periodicos/arq_pdf/a_628.pdf

Olson, M. (1971). The logic of collective action: public goods and the theory of groups. Cambridge: Harvard University Press.

Perobelli, F. F. C., Lopes, B. S., \& Silveira, A. M. da (2012). Planos de opções de compra de ações e o valor das companhias brasileiras. Revista Brasileira de Finanças, 10(1), 105-147.

Rosen, S. (1982). Authority, control, and the distribution of earnings. The Bell Journal of Economics, 13(2), 311-323.

Santerre, R. E., \& Neun, S. P. (1986). Dispersion and dispersion compensation. The Review of Economics and Statistics, 68(4), 147-197.

Santos, A. B. dos, \& Perobelli, F. F. C. (2009) Reação do mercado à deliberação de planos de opção de compra de ações: um estudo de eventos para as empresas negociadas na Bovespa. Revista Brasileira de Finanças, 7(2), 164-195.

Schiehll, E., Terra, P. R. S., \& Victor, F. G. (in press). Determinants of voluntary executive stock option disclosure in Brazil. Journal of Management and Governance. doi: 10.1007/s10997-0119179-0

Silveira, A. M. da, Leal, R. P. C., Carvalhal-da-Silva, A. L., \& Barros, L. A. B. C. de (2010). Endogeneity of Brazilian corporate governance quality determinants. Corporate Governance an International Journal of Business in Society, 10(2), 191-202. doi: $10.1108 / 14720701011035701$

Sousa, A. C. F., \& Esperança, J. P. A. (2012, novembro). Determinantes da remuneração dos gestores em Portugal e no Brasil. Anais do Encontro Luso-Brasileiro de Estratégia, Lisboa, Portugal, 4. Retrieved from http://elbe2012.iscte-iul.pt/es/papers

Sternberg, L., Leal, R. P. C., \& Bortolon, P. M. (2011). Affinities and agreements among Brazilian shareholders. International Journal of Disclosure and Governance, 8(3), 213-228. doi: 10.1057/jdg.2011.6

Victor, F. G., Carvalho, E. M. de, Funchal, J. A., \& Terra, P. R. S. (2010). Convergência no disclosure da remuneração de executivos no Brasil. In J. R. Fontes Filho \& R. P. C. Leal (Eds.), Governança corporativa: internacionalização e convergência - os novos rumos das práticas de governança (pp. 189-206). São Paulo: Saint Paul Editora.

Yokoi, Y. (2012, maio). O dono mudou? Capital Aberto, 9(105), 20-23. 


\section{APPENDIX}

\begin{tabular}{ll}
\hline Variable & Definition \\
\hline Dependent variables that measure top management and BOD compensation (Comp): \\
\hline ABC & Average BOD compensation of a company in 2009 \\
AMC & Average top management compensation of a company in 2009 \\
MMC & Maximum compensation paid to a top manager of a company in 2009 \\
TBC & Total BOD compensation of a company in 2009 \\
TMC & Total top management compensation of a company in 2009 \\
\hline
\end{tabular}

Variables that measure the degree of ownership concentration (Own):

CMIN Dummy variable equal to 1 if no shareholder or group of shareholders, bounded by a voting agreement or that belong to the same family, holds more than $50 \%$ of the voting equity capital of the company and zero otherwise

H5 Herfindahl index of concentration defined as the sum of the squared total percentage shareholdings of the five largest shareholders

H5V Modified Herfindahl index proposed by Santerre and Neun (1986):

$$
\operatorname{Min}\left\{\sum_{i=1}^{n=5}\left(\frac{\text { Percentage voting shareholding }}{i}\right)^{2} ; 1\right\}
$$

This follows the traditional Herfindahl index logic that highlights the effect of concentration, limiting, however, the index value to 1 , which occurs when one shareholder holds more than $51 \%$ of the voting equity capital alone

T1 Total equity percentage holding of the largest shareholder of the company

T1V Voting equity percentage holding of the largest shareholder of the company

T5 Sum of total equity percentage holdings of the five largest shareholders of the company

T5V Sum of voting equity percentage holdings of the five largest shareholders of the company

TG Total equity percentage holding of the largest group of shareholders bounded by a voting agreement or that belong to the same family. This variable accounts only for voting and not for stock transfer agreements. Single-family groups consist of all shareholders with the same family name or identified as relatives in the Formulário de Referência.

TGV Voting equity percentage holding of the largest group of shareholders bounded by a voting agreement or that belong to the same family. See more details in the TG definition.

Variables about the identity, top management, and BOD participation of relevant shareholders

CST Dummy variable equal to 1 if the federal, state, or municipal government holds, directly or indirectly, more than $50 \%$ of the voting equity capital of the company

CFOR Dummy variable equal to 1 if a foreign company or individual holds, directly or indirectly, more than $50 \%$ of the voting equity capital of the company

CFAM Dummy variable equal to 1 if a Brazilian individual or family holds, directly or indirectly, more than $50 \%$ of the voting equity capital of the company

NFB Number of shareholders that hold more than $15 \%$ of the voting capital of a company, or their relatives, and are BOD members of such company. The number may be a fraction of the year in the case mandates initiated during a certain year. 


\section{(continued)}

\begin{tabular}{ll}
\hline Variable & Definition \\
\hline Variables about the identity, top management, and BOD participation of relevant shareholders \\
\hline NFB\% & $\begin{array}{l}\text { NFB divided by the number of BOD members of the company } \\
\text { NFM }\end{array}$ \\
$\begin{array}{l}\text { Number of shareholders that hold more than } 15 \% \text { of the voting capital of a company, or their } \\
\text { relatives, and are top managers of such company. The number may be a fraction of the year in } \\
\text { the case service initiated during a certain year. }\end{array}$ \\
NFM\% & NFM divided by the number of top managers of the company \\
\hline
\end{tabular}

\section{Other control variables:}

TA Total consolidated assets of the company at the end of 2009

N2NM Dummy variable equal to 1 if the company belongs to Level 2 or Novo Mercado premium trading lists of BM\&FBovespa and zero otherwise

ROA08 Return on assets defined as the 2008 operating profits before interest divided by TA at the end of the same year

ROA09 Return on assets defined as the 2009 operating profits before interest divided by TA at the end of the same year

Note. We did not account for shareholdings lower than $5 \%$ of voting or non-voting equity capital of shareholders that are not part of the controlling group of the company because CVM does not require their reporting. We treated shareholders controlled by the same entity as a single shareholder and their respective shareholdings were combined in the computation of the variables relative to the degree of ownership concentration. 